HStud 26 (2012) 1, 79-91

DOI: 10.1556/HStud.26.2012.1.7

\title{
CLASSICISM AND NEOCLASSICISM IN THE POETRY OF MIHÁLY BABITS
}

\author{
JÓZSEF JANKOVICS \\ Institute for Literary Studies, Research Centre for the Humanities, HAS, \\ Budapest, Hungary
}

\begin{abstract}
Classicism or Modernity? It was not difficult to give an answer to this question for Mihály Babits, one of the most outstanding and, after a good while, most highly esteemed poets of 20th century Hungarian literature. He voted for both. Having a thorough knowledge of the Greek-Latin tradition, for him Modernity meant complete coexistence with it: "Such a respectful attitude to the past, such a loving preservation of the tradition, such conservatism is the greatest modernity. He only can be called modern who has experienced all, who carries in his mind the totality of the past, who is the pinnacle of his own times, because he unifies all ages in himself." The stress always depended on the political situation. Neoclassicism or New Classicism was his reply to the new political and cultural phenomena of the 1920s-30s.
\end{abstract}

Keywords: Hungarian literature, Classicism, Modernism, Avant-garde, Neoclassicism, Mihály Babits

Hungarian poet Mihály Babits hardly needs an introduction. However, it may be useful to give a brief overview of the defining influence and constructive role the classical heritage, the Greek and Latin language and literature played in his entire oeuvre. This influence extends to thematic and structural concerns, as well as to prosody and versification. I apply the term "classicist" to a kind of literature the formal principles of which, implicitly or explicitly, derive from Graeco-Roman antiquity, basing its materials and mythical apparatus on that tradition as an exemplary precedent to be followed, imitated, or expanded, more or less freely, as the case may be. This formulation may be appropriate also in defining 'Neoclassicism', although I believe it to apply more correctly to the second phase of Babits's Classicism.

Babits often stated that he was not to be bracketed as a believer in predestination, yet in a way he had been "predestined" to take the classical tradition further, while at the same time being in tune with modernist trends in the arts. So it is possible to say that on the one hand he showed an enduring respect for the classical authors as models to be emulated, while on the other, he did not reject innovation, 
but in fact grafted new shoots to old roots, to use the composer Béla Bartók's metaphor of his own attitude to tradition and renewal. This remarkable duality was an underlying factor in his character, his way of life, his ethical and existential Weltanschauung, even his approach to poetic form. Being both classicist and modernist was for him not a contradiction; instead, these categories dialectically completed and complemented each other. This special trait has been noticed by a number of scholars, most recently by Gergely Angyalosi, who wrote that in Babits's dualism

[...] phenomena are grasped together with their contradictions, attempting to formulate his own synthesizing viewpoint without dissolving all dichotomies. The human mind is always entertaining various alternatives; it is by 'convention' that we decide what becomes primary. ${ }^{1}$

A good example of this is to be found in the arguments between Socrates and Phaedrus in Babits's dialogue The Philosophy of Play, where in the dispute between monism and pluralism he seemingly decides to opt for the latter, while laying out the alternatives between the ascetic and hedonistic way of life. When the philosopher has almost succeeded in convincing his disciple that the value of one position can only be ascertained in juxtaposition to the other, he tells him that he "could have also formulated the whole thing the other way around [...] In the final analysis, choosing between the two world-views is a matter of convention."2

Valéria Dienes, a philosopher, theorist of dance, translator, and a disciple of Bergson who was a privy to the poet's thinking in his childhood and his student days at the university of Budapest, also observed this peculiar trait.

\footnotetext{
It is as if he were on guard to be one thing or another. It is as if he then could not feel free to become whatever he wanted to be. [...] He radiates contradictions. Restlessness is his very nature. It is my impression that as soon as he takes a firm position, he puts on a mask. [...] I heard it more than once that after defending a thesis to the point that he convinced his opponent, he added with a smile, 'But the antithesis could also be true."
}

Such a dual way of thinking is further confirmed by the fact that in spite of a life-long Catholicism, in his poetry and correspondence he at times professed to be a polytheist. "I am a polytheist and polyst, and pagan!" he wrote to his friend and fellow university student, Dezső Kosztolányi, the other major writer of the period, in August 1904. ${ }^{4}$ In his poem Credo, he provides an alternate version of the fundamental tenet of the Catholic faith:

I believe not in the one God, but in a thousand gods; in him who has given us light, in him who has given us song; 


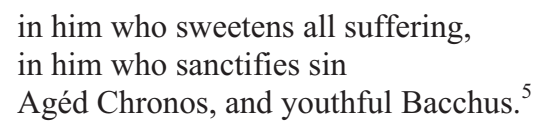

One could continue citing all the various dichotomies, the concurrent use of both induction and deduction in argumentation, the relationship between appearance and reality in his poetry, and further note the importance of the repeated emphasis in each of his works on the Nietzschean poles of Apollonian harmony and Dionysian frenzy as set forth in The Birth of Tragedy. (It may be noted in passing that not only was Babits knowledgeable about Nietzsche, but like all his great Continental and Anglo-American modernist contemporaries, he was an heir to the Romantics, and his ability to hold contrary standpoints simultaneously without privileging either would seem to echo Keats' famous negative capability principle: the state "when a man is capable of being in uncertainties, mysteries, doubts, without any irritable reaching after fact and reason".) ${ }^{6}$

We may recall Babits's answer to the question as to his favorite Hungarian poem. "Shelley's Ode to the West Wind," he had quipped, "in Árpád Tóth's translation". Tóth was Babits's contemporary, a gifted translator and fine poet in his own right.

It was Classicism, however, that became most deeply rooted in Babits's sensibility. He began his university career majoring in Hungarian and French, later switching to Hungarian and Latin. From an early autobiographical sketch written while at the university we learn that from the start he had been involved in a systematic and serious study of the classics. One after the other he read the Roman authors, devoting the most time to Sallust, but also writing a critical piece on Horace and a psycho-philological essay on Virgil's figurative language in The Georgics. Although he lost his interest in Socrates, he nonetheless translated some Plato, all the while professing a longing for Aeschylus, whom he read with great enthusiasm in Hungarian translation. From his report cards we can get a fairly clear idea about the structure and themes of the historical, rhetorical and stylistic courses he took on the ancient Greek and Roman authors.

It would seem that Babits's road to classical philology had been paved, as it were, by his family surroundings and early schooling. His father was a free-thinking jurist who took an interest in shaping the mind of his bright son, often dropping a Latin word here and there, so that by the age of ten young Mihály would scan with pleasure the "crackle and pop" of Greek hexameters, and peruse with interest picture books on Greek history and mythology. They would read to him, or he himself would read, something by Horace or Tacitus; he always had at his elbow a late edition of the earliest Latin-Hungarian dictionary. ${ }^{7}$ His first experiences in the visual arts that stirred his imagination and awakened his interest also had something to do with classical Antiquity. He was much affected by a painting, 
Nero Setting Fire to Rome, in the museum in Budapest; an album on Greek mythology he received as a Christmas present remained a life-long memory. It was a book, he wrote later,

[...] that contained images of naked men and women. Gods, mostly, but also goddesses. It was a tremendous experience. I could look at the pictures for hours on end, although I had not realized the sexual nature of the whole thing, only that I was thrilled by it in an extraordinary way. I became aware of this aspect when I had been looking at myself, in the swimming pool. While toweling off, I discovered that I, too, resembled the Greek gods. Without resorting to anything sexual. $^{8}$

Furthermore, there was his birthplace, Szekszárd (Aliscum its Latin toponym). The "Latinate cultural tradition" of the genius loci, its gentle landscape quite similar to the Tuscan hills, and the Roman relics excavated in the region, had all been instrumental in reinforcing this particular civilization in his formative years.

The next stage in his development came in secondary school, where, in addition to his studies of Greek and Latin, there were the extracurricular study groups in various disciplines. The study groups held yearly competitions, and the young Babits threw himself with relish into nearly all the essay and poetry contests. In one particular year he won, with the exception of - nota bene - poetry, first prize in every field that he entered. From this period the translations of three epigrams by Martial have recently come to light. ${ }^{9}$ He added annotations to the translations, citing also his sources. The translations contain no misreadings; in fact, they are exemplary in their skillful and precise rendering of the poet's meaning and colloquial language. And this in spite of the fact that Martial was not one of Babits's favorite classical poets.

It is thus safe to say that by the time he entered university, Babits had attained a fairly sound foundation in the classics. During his studies of Greek and Latin, in the course of a special seminar in stylistics, under the guidance of a famous professor, László Négyesy, Babits got to meet Dezső Kosztolányi and Gyula Juhász, who alongside him became two of the defining poets of the period. All three poets, each of whom came from a school in the provinces, became life-long admirers, translators, and propagators of the classical authors. By this time, however, Mihály Babits and his poet friends had acquired, through their wide readings in philosophy and literature, an ability to view the classics from the vantage point of a broader horizon. The poets' wide-ranging interests and readings had made them capable of navigating with ease in the tumultuous contemporary scene in Hungary and elsewhere in Europe, becoming aware of all the new movements in literature and the other arts. Their reading-list is impressive: in addition to the philosophers of the 17th century, we find: Spinoza, Kant, Schopenhauer, Nietzsche, Bergson, 
Emerson, Goethe, Heine, Swinburne, Lecont de Lisle, Byron, Oscar Wilde, Zola, Ibsen, Edgar Poe, Baudelaire and his circle, Carducci. At the same time they had realized that neither an exclusive adherence to the ancient models, nor the aping of the moderns, nor ascribing to the school they called "the decadents" would be sufficient in themselves. They were, in fact, quite dubious about the artistic merits of the latter. As Babits wrote to Kosztolányi in 1904,

\begin{abstract}
Just this week I've been reading quite a bit of the decadents, almost the entire Verlaine, then Mallarmé, Maeterlinck, Jean Moréas (the last is perhaps the brightest of the lot), also Rimbaud and Paul Fort, who was not really that decadent. These gentlemen have a common shortcoming: all of them are poets of a rather small caliber. In comparison, Baudelaire is a genius and a classic. ${ }^{10}$
\end{abstract}

It is important to note that Babits had given a special meaning to the term 'decadent'. According to him, decadence is the inherent characteristic of all the arts:

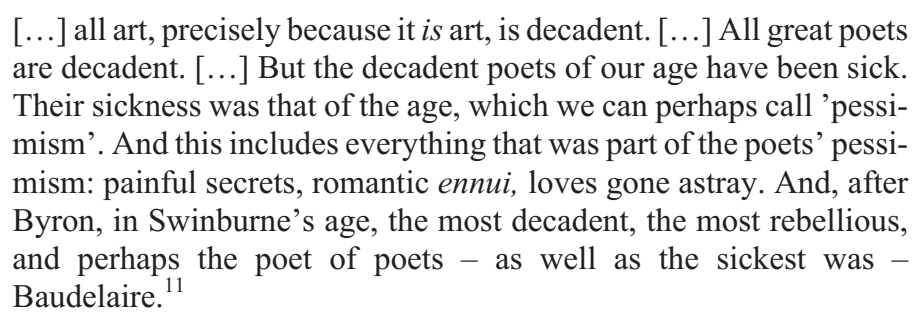

This critique can also be applied to the ancients: "Is not Horace's diction decadent?" he asks, and further, he goes back all the way to the Greeks: "Translated into modern languages, every piece in the Greek Anthology is a decadent poem."12 This does not mean that the various -isms (Expressionism, Dadaism, Activism, etc.) have the means to bring about a truly great modern contemporary poetry. In Babits's own art, a commingling of classic and modern, the two continuously strengthen each other, as noted and praised by his friend and fellow poet, Dezső Kosztolányi, already in 1906! "Modern? Much more classical. Classical? Much more powerful, colorful, new! Indeed, Sir, you embody a new direction, a novel and heretofore unseen tone and unheard music - unique." ${ }^{13}$ Kosztolányi further underlines the fact that Babits has achieved all this in Hungarian, creating an individual poetic variant of the language, which becomes in his hands not merely a tool, but creation in itself.

In a later interview Babits embraced such goals as his own poetic program, formulated in characteristically dual terms:

True poetry does not return to the past in order to reawaken the dead; such poetry flies back to the past so that in its flight it relives the spiri- 
tual reality of all the ages, to descend to the roots of human feelings emanating from the most archaic worlds, in order to show in what shape and form the human spirit has since developed, so that it would simultaneously experience the richness of the spirit from primordial times to the present. Such a respectful attitude to the past, such a loving preservation of the tradition, such conservatism is the greatest modernity. He only can be called modern who has experienced all, who carries in his mind the totality of the past, who is the pinnacle of his own times, because he unifies all ages in himself. ${ }^{14}$ (My emphasis.)

The three poets eventually went their separate ways, but it was at this time, in 1908, when Babits received an appointment as a teacher of Latin in Fogaras, now in Romania, but at the time one of the remotest corners of Hungary, in the snow-caped mountains of south-east Transylvania, that the golden period of Babits's Classicism had begun. He felt himself to be in exile in the small town inhabited by Hungarian gentry, German burgers, and Romanian shepherds, characteristically baptizing it "Tomi", after Ovid. He immersed himself in teaching and holding public lectures; in his free time he devoted himself to a more thoroughgoing study of the Greek language and literature. In one fragment he wrote without any exaggeration: "In Fogaras, with no one's help / I learnt Greek all by myself." He provides information about his readings there:

I learnt Greek in Fogaras. For a year I read practically nothing but Greek. Homer, Plato (Symposion, Phaidros, Politeia), Aeschylus, the lyric poets made the greatest impression on me. ${ }^{15}$

But he confessed: he had reached Greek literature via English poetry.

While in Fogaras, he received an invitation to submit poems to the Holnap [Tomorrow] anthology, edited in Nagyvárad (now Oradea, Romania). The poets assembled there, who included even Endre Ady, generally got bad reviews. Babits was no exception: his abstract, intellectual themes and the tone of objective lyrics were not met with enthusiasm. But Ernő Osvát, the editor of the then leading review, Nyugat [Occident], had appended a footnote to the critique that appeared in his own literary magazine, singling out Babits as the most promising. He immediately asked the "exile" to submit his new manuscripts, and so began Babits's literary career, and with it, his national renown. Several collections of his poetry were published: Leaves from the Wreath of Iris in 1909, followed by Prince, Winter Can't Be Far Behind, in 1911, and his verse drama Laodameia the same year. This was Babits's "Greek period", at the beginning of which we find the poems resulting from his Italian journey in the summer of 1908 (Zrínyi in Venice, Italia, Recanati, San Giorgio Maggiore). In the background of the latter one sees the past 
looming, together with historical reminiscences. Hungary is also present, either as parallel or antipode.

The majority of the poems written in Fogaras were included in the second book with the evocative title, Prince, Winter Can't Be Far Behind. Babits's main objective had been to correct the image with which he was erroneously branded by the reviewers of the Holnap anthology, namely that of a revolutionary subversive, an obscure poet, in order to be seen in a more balanced light. "My aim is to publish my best poems", he wrote, "so that I would win over those who were repelled by the brutality of the poems in Holnap." ${ }^{\text {"16 }}$ Even certain parts of Kosztolányi's generally positive words he found to be misguided. He was shaken to the core, finding the "public clamor" something alien to his ears. He thought that by "hellenizing" his poetry he could reclaim the image of the respectful upholder of tradition, while hoping for a renewal in the material and spiritual reality of antiquity. ${ }^{17}$ Babits originally had intended to call the book Classical Dreams, but he was dissuaded from doing so, so he used this as the title of a poetic cycle. However, the cycle speaks for itself: the masques or personae emanating from the poet's inner world are imbued with tragedy. Reality had become, instead of a Dionysiac joyfulness and gaiety, something demonic, and the poems were transformed into epilogues of tragic conflicts and fall. As the title indicates, the poems were conceived as Apollonian dream (Héphaisztosz, Homérosz, Protesilaos, Két növér, A sorshoz, Bakhánslárma, Thamyris, Danaidák, Új leoninusok, A Campagna éneke). According to G. F. Cushing, a professor of Hungarian Studies in London, one can discover in these poems the influence of the Anglo-Grecian poetic tradition on Babits's work, particularly that of Tennyson and Swinburne:

\footnotetext{
The Bakhánslárma is a presentation of the demoniac, the Klasszikus álmok gives us the mystic, Thamirys the unrepentant classicist. In $U_{j}^{\prime}$ leoninusok just as in Danaidák, along with Mozgófénykép classical verse form is applied to modern times. Óda a szépségröl especially shows Swinburne's influence. ${ }^{18}$
}

Protesilaos and Danaidák constitute a sort of preamble to the major work for Babits's Greek period, Laodameia. This "dramatic poem", according to the poet's own generic classification, is a "lyric situation" "bearing the formal elements of tragedy," inspired by Swinburne's Atalanta in Calydon. Babits's own text is inlayed with intertextual borrowings from a number of Greek and Roman authors, such as Sappho, Horace, Catullus, Homer, and Aeschylus. The theme is reinforced by powerful melodic versification, a kind of "orgy of rhythm". According to György Tverdota, "This tragic poem is the poet's most faithfully Nietzschean and most Hellenic creation." 19

Given Babits' inherent dual sensibility, it is no surprise that in this period of excessive Classicism and cult of beauty, coupled with verse turning into music, we 
find him rebelling against his own poetic platform. Already at the end of 1910, when writing Laodameia, he had completed a text entitled Epilogue to a Book of Poems, whose original, and quite revealing, title was Disgust, somewhat later $\mathrm{Na}$ ive Disgust. He submitted it, together with Divina machina, and Pro mortuis ignotis, to the editorial office of Nyugat in Budapest. However, when he received the galley proofs in Fogaras, he decided not to send them back to the editors. "I get into a nervous state when I reread these poems," he confessed, "I simply cannot convince myself to see them published in Nyugat. ${ }^{20}$

His new voice, his avant-garde experiment was so peculiarly astonishing, even for the author himself, that he withdrew his proofs. His poetic rebellion came too early for him, he could not bear the consequences of the rapid and radical change in his poetic expression. For the poem, indeed, contains a number of unusually candid revelations:

Phooey, I am disgusted with myself

myself and my poems,

I got sea-sick

from all the rolling rhythms...

Phooey, I am disgusted with everything classical

what's classical and beautiful

I have to spit at all that beauty

because all beauty is a lie.

Phooey, I have a lot of lies on my conscience

a lot of lies and beauty,

creation of beauty

virtues worse than sins.

From now on I will sing just like this, without rhythm

without rhythm and rhyme,

and I will sing of the horse on the street.

I will sing of everything that's ugly

of old hags and of mud,

of melting snow and drunken notary publics.

From now on I will sing like this

without rhythm and rhyme

using the most prosaic expressions

the more prosaic the better:

that's my poetic resolve.

If others heap insults on beauty

they are rank barbarians

who do not know whereof they speak

but if I heap insults on beauty, on poetic form

that is the holiest of blasphemies. 


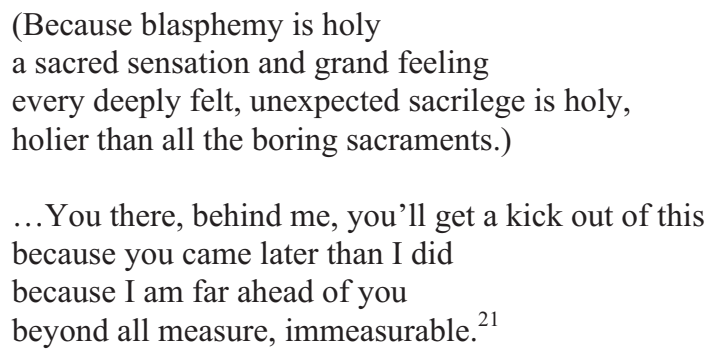

When Babits wrote these lines, Endre Ady had already published his New Poems and the notorious volume of Blood and Gold; Lajos Kassák, the great iconoclast and innovator of Hungarian verse, had also published his first works, but Babits, using this shocking new style, had preceded them both. Disgust can be seen as a rare poetic outburst, since Babits later repudiated this sort of extreme avant-garde approach, or at least did not allow such texts to be published. And while in his next books of poems he did experiment with loosening both diction and prosody, even with vers libre, in all his later work and in general he shied away from any radical breaking down of poetic form.

In the same year he likewise refused to show solidarity with Marinetti and his movement, although the Futurist had laid siege to the common enemies of "Paralysis and Podagra":

\begin{abstract}
We have already surpassed what the Italians are now attempting to do in their infantile enthusiasm; to us it is not modernity but a parody of modernity. Here in Hungary only third-rate imitators of Ady are clinging to intellectuality; only small-town writers aim to find pleasure in perversions, like the high school student dreaming of forbidden fruits. The automobile, too, has become an obsolete poetic requisite, at least since many of us had put in it death as chauffeur; and we Hungarians have grown disgusted with politics and with cursing Austria. Nor is imitating Nietzsche an attractive proposition since Nietzsche's ideas have become so fashionable. For many years the journal Nyugat has amply demonstrated that poetry is modern when it is poetry, and not when it is modern. ${ }^{22}$
\end{abstract}

He also takes to task some Hungarian Avant-garde poets regarding the publication of their journal (Tett) [Action] in 1915-1916. Lajos Kassák and his colleagues had believed that they, following the German Activists and Russian Futurists, had embarked on the uncharted waters of the Hungarian Avant-garde. In his rebuke of those who proposed to throw all tradition and all form overboard, Babits issues a warning:

This sounds great, but the important question is: is it at all possible, and if so, will the result be art? Holding onto tradition is indispens- 
able in the arts, since the essence of the arts relies on traditional precedents. In a certain sense art is a kind of expression, and in its effects not dissimilar to those of language. To be effective, language must operate by conventions and by making use of its inherited treasure-hoard. ${ }^{23}$

Furthermore, he draws attention to the fact that the prose poem and verse libre are not exactly revolutionary inventions in literature. Form cannot simply be discarded, since with the act of discarding new forms arise, and their newness is far from certain, as can be seen in the case of the prose poem.

The traumas affecting Hungary in the aftermath of World War I, the Hungarian Soviet Dictatorship of 1919, and the Treaty of Trianon (1920-1923) inevitably left their mark on Babits's poetic thinking and practice. While not reverting to his flirtation with the Avant-garde in 1910, he did admit that he could not continue his former commitment to a classical arrangement of form and content. As he said in an interview in 1923:

The classical dreams, the tranquil search for beauty have come to an end. The tensions and contradictions of life in Hungary have opened up for me in increasingly frightening magnitude. [...] During the first phase of Nyugat I had felt an overriding concern for the Great Poem, the need for a poem that was hard, triumphant, dazzling as a diamond so as to harden Hungarian poetry in contrast to the grey and sloppy thing it had almost become. [...] The present time calls for other lessons: today content is more important than form; that is why I have turned increasingly to writing free, unrhymed, even sloppy poems, and have written more and more in prose. ${ }^{24}$

He announces the same program at the publication of his volume The Island and the Sea, in 1925:

"Sappho's days faded long ago" - this is what I write in the first poem of the book, and indeed, we have come far from the times of beautiful poems, of rhymes and melodies, when the private dejections, loves, and sorrows of the poet moved the heart of the gentle reader. [...] We live in such times when all of our life is hanging by a thread. [...] In my new book the emphasis lies on the above-mentioned content, while in its form it is quite plain, not wanting to dazzle either with virtuosity or by taking liberties. We have had quite enough shouting; what we need now, I believe, is speaking in a quiet, serious manner. I see a great deal of barbaric turbulence swirling all around, while for many the credibility in a cultivation of the spirit has been shaken, as the world has been caught up in sport and dance. [...] The poet still dreams of other sports, of other dances, which are filled with spirit as in the time of the ancient Greeks, and woe to the poem that wants to be only physical, only legs and fits. ${ }^{25}$ 
Thus the poet signals the constant and variable features of his art; the Hellenic ideal, which he first set aside for personal reasons in the early 1910s, and later for political considerations, is now once again ready to rise to the surface.

In a formidable essay written in 1925 Babits announces the need for a new Classicism:

\begin{abstract}
Now that we have discovered the dark side of the world, we need to rediscover the whole world, in its totality, together with its neglected spirituality, with its nearly forgotten luminous side. What else could this be named than a road to a new Classicism? It does not mean the negation of naturalism: on the contrary, the aim is to make use of it and bring it to fulfillment by returning to the natural, continuously diminishing and increasing totality of Eternal Art. But content now again plays a role, not to be lost in empty artifice. Invention and plain talk happening simultaneously, carrying a new and modern message, of the present, to the present. New, because it is a revelation, and modern, for the first time, because it is a revelation of the spirit. ${ }^{26}$
\end{abstract}

In a 1931 interview on contemporary literature he once again deploys the formula of the new Classicism against a new cultural phenomenon:

\begin{abstract}
In my view the time is ripe for a new Classicism, an eruption of a new intensity. [...] I am once again emphasizing the importance of form. In the contemporary literary scene we are faced with a dangerous and ominous threat: a literary school where literature and mere reportage are confused. ${ }^{27}$
\end{abstract}

The last ten years of Mihály Babits's life were spent under the aegis of this new Classicism and also in great physical suffering. By this time he had finished the translation of La Divina Commedia, which he had begun in Fogaras. By early 1927 he had completed his major prose work, the novel Halálfiai, [which means, "those who are about to die", but could also be translated as "The Walking Dead"], some of which is based on autobiographical details. His translations, including Goethe's Iphigenia in Tauris, were published in 1931, and he also completed a translation of Sophocles' Oedipus, the King. The following year sees the publication of a translation of medieval hymns with the title Amor Sanctus. In 1934 he conceived plans to write a "modern" play based on the tragedies of Euripides, even though earlier he had felt a certain distance from the dramatist because of his perceived "unbridled enthusiasm".

In February 1938 he underwent surgery to remove a tumor from his trachea, and he lost his ability to speak. During the summer of the same year he wrote his great poem about the Hebrew prophet's confrontations with God in The Book of Jonah. In this work the poet also confronts himself, affirming his view that some- 
one singled out to be a prophet cannot refuse his vocation. As György Tverdota has observed, Babits in his anguish has been "refined" - a term, incidentally, that Dante applied to Arnaut Daniel in the Purgatorio - to pass from his earlier pagan polytheism to being a champion intent on preserving cultural tradition. ${ }^{28}$ Even in his constant pain and discomfort Babits nonetheless continued to cling to the classics. From 1940 onwards, while being subjected to antispasmodic medication, enemas, and catheterization, he persevered in translating Sophocles and prepared his inaugural lecture for the Hungarian Academy of Sciences. Even amidst the horrific humiliations besetting mind and body he continued to hold on. In his conversation books, Beszélgetöfüzetek, used as his sole communicative device, he gave Latin lessons to his daughter Ildikó.

Babits's life came full circle on August 4, 1941. On the night table by his death-bed there lay the corrected proofs of Sophocles' Oedipus in Colonus, ready for the printer. The last drama of the Greek tragedian is also the last translation and work of the Hungarian poet. The figures of the blind king and the voiceless poet seem to overlap: Mihály Babits had inscribed traces of himself into the character of his protagonist. These details have come to light in György Poszler's close study of the conversation books, and Poszler also gives an apt summary of the essence of Babits's Classicism and Neoclassicism:

\footnotetext{
The [Oedipus] translation is the consummation of his creative life, leading back to the very roots, to the ideals inspired by Graeco-Roman, that is to say, Mediterranean, Classicism. Which is at the same time an affirmation of the Humanistic ideal, which is indestructible, without the need to qualify or restrict its meaning. He is, of course, a modern classical ideal. Not purely Apollonian, nor wholly Dionysian, but a gently modified fusion of the two. ${ }^{29}$
}

The shortened version of the paper was read in Rome, September 2009, at a conference organized by Foundation CINI, the Hungarian Academy of Sciences, and the Hungarian Chair of the University La Sapienza with the title: L'eredità classica nella cultura italiana e ungherese nell'Ottocento dal Neoclassicismo alle Avangardie.

\section{Notes}

1 Gergely Angyalosi (2008) 'Szárnyaska szamár az őszi kertben - József Attila Babits-képéről' Literatura, Vol. 2, 199.

2 Mihály Babits (1978) Esszék, tanulmányok, ed. György Belia (Budapest: Szépirodalmi), Vol. 1. 311.

3 Ágnes Kelevéz (2008) »Kit új korokba küldtek régi évek« - Babits útján az antikvitástól napjainkig (Budapest: Petőfi Irodalmi Múzeum), 122. 
4 Babits Mihály levelezése (1890-1906), ed. Sándor Zsoldos (Budapest: Historia Litteraria Alapítvány-Korona Kiadó) 1998, 97. (Series: Babits Mihály Műveinek Kritikai Kiadása, Levelezés, ed. by Lajos Sipos)

5 Babits Mihály Összegyüjtött Versei ed. Ágnes Kelevéz (Budapest: Századvég Kiadó), 1993, 152. - All the quotations here are translated by dr. László Géfin.

6 The Letters of John Keats. Ed. Maurice Buxton Forman. 3rd edition with revisions and additional letters (London, New York and Toronto: Oxford University Press), s. d. 72.

7 Dictionarium Latinoungaricum, item vice versa Dictionarium Ungaricolatinum, per Albertum Molnár Szenciensen Ungarum. Nürnberg, Hutterus, 1604.

8 Mihály Babits (1993) "Itt a halk és komoly beszéd ideje" - Interjúk, nyilatkozatok, vallomások, ed. János Téglás (Budapest: Pátria Nyomda), 45.

9 Attila Buda (2007) Teremtő utánzás - Babits-tanulmányok (Budapest: Ráció Kiadó), 139-64.

10 Babits Mihály levelezése (1890-1906), op. cit., 111.

11 'Swinburne', Esszék, tanulmányok, op. cit., Vol. 1, 35-6.

12 György Tverdota (1997) 'Klasszikus álmok. Dekadencia és antikvitás Babits első korszakának költészetében’, Irodalomtörténeti Közlemények, 569.

13 Babits Mihály levelezése (1890-1906) op. cit., 236.

14 'Itt a halk és komoly beszéd ideje'op. cit., 137-8.

15 'Itt a halk és komoly beszéd ideje', op. cit., 20; Ágnes Kelevéz, op. cit., 120.

16 In one of his letters to Gyula Juhász.

17 György Rába (1981) Babits Mihály költészete 1903-1920 (Budapest: Szépirodalmi), 287.

18 G. F. Cushing (1948) 'Babits és az angol klasszika-filológia' Irodalomtörténet, 604-05.

19 György Tverdota, op. cit., 571.

20 Ágnes Kelevéz (1998) A keletkezö szöveg esztétikája. Genetikai közelítés Babits költészetéhez (Budapest: Argumentum Kiadó), 87.

21 Babits Mihály Összegyüjtött Versei, op. cit., 538-41.

22 Babits Mihály világa (1983). Centenáriumi emlékülés Kaposváron. Ed. András Laczkó (Kaposvár: Somogy Megyei Nyomda), 13.

23 Mihály Babits 'Ma, holnap és irodalom. Ars poetica forradalmár költők használatára', Essszék, tanulmányok, op. cit., 440.

24 'Itt a halk és komoly beszéd ideje', op. cit., 73-74.

25 Ibid., 94.

26 'Új klasszicizmus felé', Esszék, tanulmányok, op. cit., Vol. 2, 157.

27 'Itt a halk és komoly beszéd ideje' op. cit., 172.

28 György Tverdota, op. cit., 568.

29 György Poszler (1984) 'Babits beszélgetőfüzetei’, Irodalomtörténet, 550. 